\title{
EDITORIAL
}

\section{A practical guide to the supportive and palliative care of patients with chronic kidney disease}

We are sure that all of us involved in the field of renal medicine in South Africa would agree that the guidelines, published on page 86 of this issue, around the supportive care of renal patients, especially those who cannot access renal replacement therapy - produced in collaboration between the South African Renal Society and the Association of Palliative Care Practitioners of South Africa - will prove valuable in assisting us in making difficult decisions and in providing constructive advice on the management of our patients with advanced chronic kidney disease (CKD).

South Africa's GDP per capita, of around US\$3600, places it within the upper-middle-income economic group. Unfortunately, our economy must cope with limited resources with the burden of both non-communicable and communicable diseases. We have one of the highest prevalences of HIV infection in the world, with high frequencies for the APOLI GI and G2 risk alleles for HIV-associated (and other) nephropathies [I]. The World Health Organization's Global Health Observatory (https://www.who.int/data/gho) reports the crude prevalence of hypertension in South Africa at $24 \%$, diabetes at $9.8 \%$, overweight at $51.9 \%$ and physical inactivity at $37.2 \%$.

The South African Renal Registry [2] reports that $84 \%$ of South Africans rely on state-funded medical facilities. A metaanalysis by Kaze et al. [3] quotes the prevalence of CKD stages 3 to 5 to be around $4.8 \%$ of the population in subSaharan African countries, and in South Africa this amounts to some 2.7 million people with significant kidney disease. Considering our risk profile for renal disease, this is unlikely to be an overestimate. According to the renal registry, only around II 000 individuals in South Africa are on dialysis or have functioning kidney transplants, with 3100 served by the public sector. Unfortunately, our transplantation rate is low - $4.8 \mathrm{pmp}$ in the public sector and $15.2 \mathrm{pmp}$ in the private sector between 199I and 2015 [4].Transplant centres in the UK reported adult deceased donor renal transplant rates between 24 and 66 per million population in 20/8/19 [5].

We have large numbers of individuals with end-stage renal disease (ESRD), who are on a palliative care path, not by choice, and this is distressing. These guidelines should not be a substitute for ongoing efforts by our government to "move as expeditiously as possible towards the full realisation of the right to healthcare services", as enshrined in Section 27 of our constitution.

We congratulate our nephrology and palliative care community, and thank our visiting Australian colleagues, for well thought out and practical guidelines, which cover all aspects of supportive care for ESRD patients, including effective and caring communication, symptom management, preserving renal function, end-of-life care, care of paediatric patients, and models for setting up a renal palliative care service. The South African Essential Drugs List was used where possible to ensure that the medications are universally available in South Africa.

\section{Graham Paget and Vakhtang Rekhviashvilli \\ South African Renal Society}

\section{REFERENCES}

I. Kasembeli AN, Duarte R, Ramsay M, Mosiane P, Dickens C, Dix-Peek T, et al. APOLI risk variants are strongly associated with HIV-associated nephropathy in Black South Africans. J Am Soc Nephrol. 2015; 26:2882-2890.

2. Davids MR, Jardine T, Marais N, Zunza M, Jacobs JC, Sebastian S. South African Renal Registry Annual Report 2017. Afr J Nephrol. 20I9; 22:60-7I.

3. Kaze AD, llori T, Jaar BG, Echouffo-Tcheugui JB. Burden of chronic kidney disease on the African continent: a systematic review and meta-analysis. BMC Nephrol. 2018; 19:125.

4. Moosa M. The state of kidney transplantation in South Africa. S Afr Med J. 2019; 109:235-240.

5. Annual report on kidney transplantation 2018/19. NHS Blood and Transplant (2019). https://nhsbtdbe.blob.core.windows.net/umbraco-assetscorp/I7289/kidney-annual-report-2018-19-november19.pdf. Accessed 5 May 2020. 